\title{
Mining the International Guidance on Mining
}

\author{
John Southalan \\ Adjunct Associate Professor (Centre for Mining, Energy and Natural Resources Law, The University of Western Australia), \\ Global Faculty (Centre for Energy, Petroleum and Mineral Law and Policy, University of Dundee), Resources Law Network \\ Perth, Australia \\ john@ southalan.net
}

\begin{abstract}
The last five years have produced many reports and guidance on how mining should occur to better balance its broader benefits and impacts. There are copious recommendations for government regulation and also for responsible company conduct. This article summarises the main documents here, together with broader dynamics in government regulation, and identifies some lessons these may provide for mining regulation in Indonesia. This includes local content, human rights, and governance.
\end{abstract}

Keywords - mining, regulation, Indonesia, local content, regulatory impact assessment, human rights

This paper summarises recent studies and recommendations about how governments should regulate mining, and identifies some as pects of particular relevance to Indonesia. This is presented underfourheadings .

(I) International trends,

(II) Indonesia-specific materials,

(III) Broader regulatory dynamics, and

(IV) Concluding observations.

\section{INTERNATIONAL 'TRENDS'}

The last decade has seen a vast amount of publications suggesting how states should regulate mining. The following is a form of 'literature review' of the more relevant material. Each work is given one sentence summary, followed by a description of its production/authorship, and then a brief outline of its contents or analys is. This should be read with the caveat that these materials do not present a summary or 'average' of what currently exists in countries with extensive mining. Much of the following is aspirational in outlining why and how improvements should occur in countries' mining regulation. Such recommendations are easily made at the international or academic level because those authors do not have to actually implement that regulatory regime, nor manage competing interests. Nevertheless, international guidance and standards do provide a useful measure and ideas for improvements in domestic mining regulation.

\section{A. Open Contracting (2018) [1]}

This recommends governments need to improve transparency across the entire process by which they award extractive rights... [including] all stages of ... planning, allocation and award of rights, and information about contract terms and their implementation'([1], p3). The report arises from joint research of the Open Contracting Partnership and Natural Resource Governance Institute (NRGI). The original research for was work they conducted for Mexico's National Hydrocarbons Commission about best practices for transparency in contract management. This was expanded with interviews with practitioners and researchers from nine countries of varying extractive-intensivity and economic development, and also reviewing data from NRGI's 'Resource Governance Index', and surveys of contracting processes in the Democratic Republic of Congo, Indonesia, Myanmar, Nigeria and other countries. The report contains six chapters: Introduction, Overarching Issues: The System and The Actors Involved, Planning, Allocation and Award of Contracts and Licenses, Contract, and Implementation. The report summarises its content into the following 16 recommendations, and usefully provides examples (and URLs) of various government programs which are considered good practice.

1 Use joined-up information to explain the contracting systemin full.

2 Reconcile information needs of both companies and citizens.

3 Communicate who the decision-makers are.

4 Disclose information about the areas to be opened to extractive industry contracting and why.

5 Reconcile sub-surface and surface rights and the needs of their users.

6 Publicly explain the choice between different allocation methods and how they apply in different situations.

7 Communicate early that allocation is happening.

8 Publish the rules of the game.

9 Disclose who stands to benefit.

10 Disclose regulator engagement with prospective companies.

11 Conduct and disclose consultative processes.

12-15 Disclose allocation outcomes, contracts, investment, production and reserves, revenues and benefits.

16 Track and dis close contract compliance.

\section{B. Local content policies: Guidance for Governments} (2018) [2]

This detailed Guidance (90pp) 'aims to help governments in the essential task of deciding what (if any) local content policies are appropriate to their unique settings, what supporting policies and partnerships are needed, and how those policies can be successfully implemented' ([2], p iv). The report was produced by the Intergovernmental Forum on Mining Minerals Metals and Sustainable Development, as a Guidance for its members and other governments. The contents are arranged under the Guidance's main recommendation, with each chapter providing detailed commentary, case studies, and assistance on that topic. The main points are listed below. 
3.0 Step 1: Ensuring a Fit with NationalDevelopment Objectives

4.0 Step 2: Taking Stock

4.1 Understanding the Sectoral Context

4.2 Appreciating Current Opportunities and Future Challenges

4.3 Prerequisites: Other key elements of the scan

4.4 Possible Risks of Ill-Designed Policies

5.0 Step 3: Crafting the Policies

5.1 Local Procurement

5.2 Local Direct Employment

5.3 Horizontal Linkages: Development beyond the mining sector

5.4 DownstreamLinkages: Beneficiation of mining products

5.5 Building Domestic Capacity: Fostering national mining firms

6.0 Step 4: Monitoring, Review, Enforcement

7.0 Cross-Cutting Concerns

7.1 The Challenge of TechnologicalEvolution

7.2 The Challenge of International Trade and Investment Law

Chapter 5, on drafting local content policies, is the bulk of this report and contains useful detail on the economic and political considerations in relation to each of the topics it covers and how these may reinforce the governments approach and structures.

\section{Responsible Mining Index (2018) [3]}

This does not focus on government regulation of mining, but is instead a report on large-scale mining companies' actions on economic, environmental, social and governance issues across their mining activities. The assessment is based on publicly available information on these companies and mine sites, measuring both company-wide behaviour and also site-level actions at 127 mines. It does not purport to be an independent survey of each companies' performance but measures the company's commitments, procedures and review of its actions. The relevance for this, to those interested in government regulation of mining, is that it helps indicate what may be expected from the large-scale company (and thus helps inform areas for attention). ${ }^{1}$ The Index provides detail, against six themes (Economic Development, Business Conduct, Lifecycle Management, Community Wellbeing, Working Conditions, and Environmental Responsibility) for 30 companies. Of most interest to government regulation of mining is the Index's 'key findings', extracted below.

1 Responsible mining 'can be done...[it] is a realistic goal ...existing best practice, if systematically applied by all companies, could already go some way to meeting society expectations.

2 [There is a] Diversity of responsible practice ...performance does notnecessarily depend on the company size or commodity focus, the home countries where they are regis tered, or the producing countries where they operate.

3 Commitments need to be realised. The vast majority of companies have made policy commitments on topics such as ... human rights, occupational health and safety, and environmental impact management ...[but] few companies can demons trate that they have systematically operationalised their commitments into effective actions and fewer still show they are tracking their performance on these is sues....

5 External requirements improve public disclosure....

6 From case studies to systematic action. Stronger performing companies generally demonstrate companywide approaches to managing EESG [economic, environmental, social and governance] is sues, rather than only being able to show action in a specific mine site....

7 Site-level data [is] largely mis sing ...

8 Open data sharing [is] still evolving' ([3], p12-13).

\section{Managing mining for sustainable development (2018)}

[4]

This detailed sourcebook (103pp) 'brings together existing knowledge, experiences and tools to help equip governments and communities in resource-rich countries ... to manage mining ... consistent with their aspirations for sustainable development. ...[I]t is within the power of governments of resource-rich countries to protect people and the environment and to realize the benefits from mining, working alongside the mining industry and local communities' ([4], p4). The book was produced by UN agencies with extensive input from government, industry and academic expertise and peer-review. It contains three main sections, after some introductory chapters on mining and sustainable development, covering (1) legal frameworks, (2) protecting the environment and people, and (3) the economic \& developmental benefits from mining. The recommendations regarding these three sections are extracted below, and indicate the issues and assistance in the sourcebook

'Orienting legal frameworks towards sustainable development

- Making domestic laws and regulations coherent with each other and sufficiently detailed to function as the core set of instruments for governing mining

- Improving coordination between government agencies and between national and subnational governments

- Considering moving fromcontract-based regimes to lawbased regimes, avoiding using mining contracts to fill legal and regulatory gaps

- Considering establishing model agreements which provide the policy space for environmental and social laws of the country, and limiting terms that are open to negotiations

- Where mining contracts are made, paying special attention to provisions related to environmental impact mitigation, mine closure, resettlement, local content and employ ment

- Ensuring transparency of mining contracts, including disclosure of beneficial ownership

- Assessing implications of international investment treaties on the country's commitments to sustainable development, human rights and the domestic policy space; negotiating terms in investment treaties to minimize these negative implications

- Incorporating or streng thening the principles of consultation with local communities and free, prior and informed consent in domestic laws and regulations; and establishing
However it is important to note the Index's caveat that 'RMI recognises, but does not attempt to measure, the influence of external institutions on company behaviour, such as laws and regulations est ablished by producing country governments, conditions set by invest ors, or frameworks and standards provided by voluntary initiatives': [3], p8. 
or strengthening state remedy mechanisms for people affected by mining

- Making use of voluntary standards developed by and for the mining industry, encouraging res ponsible mining investments and recognizing companies that adhere to strong standards

- Recognizing and progressively registering customary land rights to protect poor and marginalized rural communities and indigenous peoples' ([4], p4).

'Protecting the environment and people

- Designing environmental regulation that adequately protects the environment, which also es tablis hes clear rules for investors

- Where capacities of the government and the mining industry allow, considering adoption of more innovative approaches to environmental regulation, such as performance-based regulation and economic incentives

- Making requirements for EIA and EMP for the mining industry, setting outclear roles for the government, mining companies, environmental services experts, civil society organizations and community groups

- Establishing laws and regulations for mine closure that prevent large environmental legacies and public costs

- Ensuring that affected communities are informed in advance of mining projects about land use options which are available after mine closure

- Investing in capacities of regulators for monitoring and enforcement of regulations

- Improving intra-governmental coordination mechanisms, such as those between mining and environmental minis tries, local governments, human rights commis sions and other government agencies

- Enhancing access to mining-related information that is important and relevant to local communities

- Fostering a culture of trans parency in the government and in the mining industry

- Opening legal avenues for local communities and indigenous peoples affected by mining to have a say in mining projects; defining minimum standards for adequate consultation and consent; investing in the capacities of communities affected by mining; and providing access to remedy for people affected by mining' ([4], p17).

'Realizing and enhancing the benefits from mining

- Designing and instituting progressive fiscal regimes that balance between the financial returns to the country (or the government) and those to the mining companies, in line with international comparis ons

- Making use of tools such as project-level mining fiscal models to es timate the government "take" frommining projects to design fiscal regimes and negotiate with mining companies

- Ensuring that the fiscal regime is stable overtime, which in the long term would help to move towards greater reliance on legal frameworks, rather than mining contracts

- At the same time, ensuring flexibility of the fiscal regime to respond to the cyclical nature of the minerals and metals commodities markets, by building in contract negotiation clauses

- Ensuring transparency of the fiscal regime (in the flows of resource revenues and in mining contracts) and access to information, by drawing on international transparency initiatives such as the EITI; ensuring a relatively straightforward fiscal regime that does not obscure transparency; and fostering an overall culture of transparency

- Managing the volatility of resource revenues by using tools such as structural budget rules developed by the International Monetary Fund (IMF), and designing and ins tituting natural resource funds

- Investing resource revenues in a way that increases (or does not deplete) the national wealth, into infrastructure, social service provision, financial as sets and alternative sources of growth, setting priorities that are consistent with the country's level of development and needs

- Using a combination of strategies to improve the competitiveness of domes tic workers and firms and to set local content requirements to help enhance the benefits from the mining sector for employment, business development, and economic growth

- Collaborating with and fostering collaboration between mining companies in order to design and implement local development initiatives, community development agreements and skills development initiatives

- Supporting the capacity of local communities impacted by mining to take greater advantage of local development opportunities

- Encouraging local development initiatives by mining companies to be synergized with government plans and programmes

- Integrating the country's mining sector strategies with other plans and policies, such as national and regional development plans, fiscal revenue projections and budget plans, macroeconomic policies, land use plans, infras tructure plans, public service delivery plans, human resource development plans and education policies; and ensuring coherence between plans, policies, strategies and laws' ([4], p20).

\section{E. Sustainable Minerals Development: Best Practices in} ASEAN (2017) [5]

Despite its title, this document is a summary of the operations of the finalists of the 1st ASEAN Mineral Awards, which included companies undertaking nickel mining in the Philippines; limestone quarrying in Thailand; ferronickel processing in Indonesia, and distribution of copper concentrates from Indonesia ([5], p1).

ASEAN, like other regional government groupings, has framed some guidance about mining. ${ }^{2}$ The current version the third ASEAN Minerals Cooperation Plan - was adopted in 2015 [8], with its aim 'to create a vibrant and competitive ASEAN mineral sector for the well-being of the ASEAN people through enhancing trade and investments and strengthening cooperation and capacity for sustainable mineral development in the region' ([8], p1). The aim is commendable but the detail on how that is achieved appears not to be matter for regional agreement and specification. ${ }^{3}$ While the Plan covers the following range of topics, most are about cooperation and exchange between ASEAN governments, rather than specific guidance on what those eg. the African Union [6] and European Commission [7]

The difficulties of achieving agreement at an international level are always present and often result in rather vague statements, like the second 'Objective' of this document being that ASEAN member states will 'strive... to promote environmentally and socially sustainable mining practices': [8], p3-4. 
governments should be doing in regulating mining within their countries.

II. The ASEAN Minerals Cooperation Action Plan 20162025 (AMCAP-III)

A. Vision

B. Objective

C. Policy Agenda and Areas of Cooperation

D. Review of AMCAP-II

E. Implementation Arrangements

III. AMCAP-III Phase 1: 2016-2020

IV. AMCAP-III Phase 2: 2021-2025

Implementation Details of AMCAP-III Phase 1: 2016-2020

More detailed guidance is, however, provided in ASEAN's 2017 Reporting Mechanism regarding 'Sustainability Assessment Frameworks and Tools for the Minerals Sector[9]. This document 'aims to ... track ... progress and long-term performance [of ASEAN Member States] in instituting frameworks and tools to support sus tainability in the minerals sector' $([9], 1)$. The Reporting Mechanism was drafted by the 'ASEAN Senior Officials Meeting on Minerals' and subsequently welcomed by ASEAN Ministers in November 2017 ([10], p1). So the contents of this Reporting Mechanism indicate what ASEAN considers governments should be doing to support sustainability in their minerals sectors. The Reporting Mechanism will monitor adoption and implementation measures, by ASEAN governments, against the following sustainability as ses sment frameworks and tools. ${ }^{4}$

Sustainable indicators and indices, generally and also specific to the minerals sector (by reference to a 2004 academic article [11])

Indicators of the Global Reporting Initiative (by reference to their 2016 standards, eg [12])

Indicators of the Commission on Sustainable Development Indicators (by reference to their 2007 edition [13])

Product-related sustainability as sessment tools (by reference to a 2014 Thai Government publication [14])

Life cycle as sessment (referencing the same Thai Government publication)

Life cycle costing (by reference to a 2013 Australian standard [15])

Integrated assessment tools (by reference to a 2007 academic article [16])

'Environmental Impact Assessment' and 'Strategic Environmental Assessment' (both by reference to a 2017 webpage of the Irish Government [17])

F. Oil, Gas \& Mining: Sourcebook for understanding the Extractive Industries (2017) [18]

This extensive publication (298pp) 'illuminates the spectrum of integrated policy interventions necessary to transform natural resource wealth into sustainable development, ranging from the allocation of resource extraction rights to the use and distribution of revenues' ([18], p xi). In printed form, it is the 2017 collation of a range of materials from a free online interactive source ${ }^{5}$ coordinated by the World Bank and University of Dundee's Centre for Energy, Petroleum and Mineral Law \& Policy, of reports, summaries, and briefs across all parts of extractives' operations and regulation. The chapters in this report provide extensive detail on the broad economic, political and legal dynamics in the extractives sector, with chapter 4 of particular relevance to mining regulation.

1 Shifting Patterns of Demand and Supply

2 Extractives: Opportunities and Challenges for

Development

3 The Extractive Industries

4 Policy, Legal, and Contractual Framework

4.1 Knowledge Core

4.2 Getting Started: Facts of EI Life

4.3 Eight Key Challenges

4.4 Policy Priorities

4.5 Hydrocarbons and Mining Laws

4.6 Contracts and Licenses

4.7 The Award of Contracts and Licenses

4.8 Why Regulations Are Necessary

4.9 Investment Guarantees: Stabilization

4.10 Contract Negotiations

4.11 Disputes: Anticipating and Managing Them

4.12 Summary

4.13 Taking Action: Recommendations and Tools

5 Sector Organization and Regulatory Institutions

6 FiscalDesign and Adminis tration

7 Revenue Management and Distribution

8 Transparency and Accountability

9 Sustainable Development Implementation

10 Why Governance Matters

The summary in chapter four includes the following observations and guidance.

'Finding 1: Knowledge of the fundamentals of extractive industry legal and regulatory frameworks is readily available....

Finding 2: Application of this knowledge is difficult because of four distinct sources of dynamis $m$....

First, and most obviously, every country context is unique.... What is the right combination of established instruments for our particular context at this time?

Second, legacy matters.... Given this living legacy, how do new proposals manage such constraints and limit their impact?

Third, adaptation will be required.... Are formal mechanis ms in place to allow future adminis trations to make adaptations smoothly and quickly, and is the capacity there to achieve this?

Fourth, looking ahead, any choice made with respect to a combination of legal and regulatory instruments will need to be adjusted as knowledge grows and capacity increases.... What mechanisms can we put in place to allow for flexibility without creating uncertainty for future investment flows?

Finding 3: Policies are becoming increasingly differentiated among the segments of the extractives sector....

Finding 4: Countries have progressively better defined the nature of subsoil rights granted and the scope of each stage of the entire upstreamprocess, especially in hydrocarbons'[18], p106-107.

\section{G. Local procurement reporting mechanism (2017) [19]}

This reporting mechanism provides 'a set of disclos ures on local procurement...to be reported by organisations
The document says: 'Specifically, the Reporting Mechanism will monit or the Sust ainability and Assessment Frameworks and Tools adopted and/or implemented by ASEAN Member States, such as
(Appendix I)' ([9],p1) and these are outlined in the text above, from pp5-6 of that document.

5 http://www.eisourcebook.org (accessed 3 Aug 2018). 
who report on mine sites...to help standardise the way the sector and host countries talk about these issues. It facilitates comprehensive reporting on local procurement spending at the site level, as well as practicaldetails on mining company procurement processes and programmes that support better informed stakeholders' ([19], 7). This aims to: (1) improve internal company management to create more benefits for host countries, (2) empower suppliers, host governments, and other stakeholders with practical information, and (3) increase transparency in the procurement process to deter corruption ([19], 7). The reporting mechanism, developed through Engineers without Borders Canada and Germany's Extractives and Development programme, involved experience staff from industry (miners and suppliers), government and civil society. It also had extended 'in country' consultations in various countries including Mongolia. The key parts of the documents are indicated below.

Part 1: Introduction to the Mining Local Procurement Reporting Mechanism(LPRM)

Part 2: Disclosures on mining local procurement

2.1- Mining LPRM reporting requirements - What is expected?

2.2 -The Mining LPRM disclosures

Context for local procurement disclosures

Procurement systems

Local procurement spending by category

Local procurement due diligence

Methods to incentivise local procurement

External commitments and obligations

Part 3: Institutional use of the Mining LPRM

3.1- Host country LPRM uptake and use

3.2- International promotion of increased mining local procurement through use of the Mining LPRM

Concluding Remarks

H. Guidance stakeholder engagement in extractives [20] and responsible supply chains in mining [21] (2016 \& 2017)

These two documents, from the OECD Secretariat, outline guidance related to the $O E C D$ Guidelines on Multinational Enterprises. ${ }^{6}$ Each was finalised, over years, after exposure drafts and feedback (from industry, NGOs and governments) coordinated by the OECD Secretariat, before being accepted by OECD Governments. Their content is aimed at what companies should do, but are important for governments to be aware of when considering the content and form of their regulation.

The 2017 guidance on stakeholder engagement 'provides practical guidance to mining, oil and gas enterprises in addressing the challenges related to stakeholder engagement' (XX, p3). This addresses both corporate management and also 'on the ground' personnel, and also includes recommendations for specific subjects and areas in the annexures. Its contents include the following.

Due diligence framework

Recommendations for corporate planning or to management

Positioning stakeholder engagement strategically

Recommendations to on-the-ground personnel
Step 1: Ensuring that personnel leading stakeholder engagement understand the local and operating context

Step 2: Identifying priority stakeholders and interlocutors

Step 3: Establishing the necessary support systemfor meaningful stakeholder engagement

Step 4: Designing appropriate and effective stakeholder engagement activities and processes

Step 5: Ensuring follow-through

Step 6: Monitoring and evaluating stakeholder engagement activities and responding to identified shortcomings

AnnexA. Monitoring and evaluation framework for meaningful stakeholder engagement

AnnexB. Engaging with indigenous peoples

AnnexC. Engaging with women

AnnexD. Engaging with workers and trade unions

AnnexE. Engaging with artis anal and small-scale miners

The 2016 guidance on responsible supply chains has an 'objective ... to help companies respect human rights and avoid contributing to conflict through their mineral sourcing practices ...[and] is also intended to cultivate transparent mineral supply chains and sustainable corporate engagement in the mineral sector' $(X X, p 3)$. The document is the third edition of the OECD's guidance in this area. It sets out recommendations for those parties operating or using minerals from areas affected by conflict or with high risk of harm to people including 'areas of political instability or repression, institutional weakness, insecurity, collapse of civil infrastructure and widespread violence' (XX, p13). The document details a risk-based due diligence framework, provides a model supply chain policy and has further detail regarding particular minerals and areas. Its contents include the following.

Due Diligence Guidance

What is due diligence in the mineral supply chain and why is it necessary?

Who should carry out due diligence?

AnnexI. Five-Step Framework for Risk-Based Due

Diligence in the Mineral Supply Chain

AnnexII. Model Supply Chain Policy for a Responsible Global Supply Chain of Minerals from Conflict-Affected and High-Risk Areas

AnnexIII. Suggested Measures for Risk Mitigation and

Indicators for Measuring Improvement

Supplement on Tin, Tantalumand Tungsten

Supplement on Gold

\section{Chinese Due Diligence Guidelines (2015) [22]}

The Chinese Due Diligence Guidelines for Responsible Mineral Supply Chains are 'guidance to all Chinese companies which are extracting and/or are using mineral resources and their related products ... to observe the $U N$ Guiding Principles on Business and Human Rights during the entire life-cycle of the mining project' ([22], 8). The document was adopted by the China Chamber of Commerce of Metals Minerals and Chemicals Importers \& Exporters. The Guidelines requires these companies to have a risk-based, supply chain due diligence framework and, where there is risk in their supply chain, to act to reduce that ([22], p12-21). Significantly, this involves going beyond domestic law, with the Guidelines explicitly identifying risk as including: 
'Extracting or sourcing resources from land where the free, prior and informed consent of local communities ... has not been obtained, including those for which the extractor holds a legal title, lease, concession, or license' ([22], 5.2.1.4).

The Chinese Guidelines cover all Chinese companies in the minerals supply chain - miners, as well as processors and uses of the processed product. The document contains no indication of its implementation or monitoring, and so its potential is unclear but potentially vast. If Chinese smelters are to be measured against these Guidelines, those businesses will want to ensure their raw product is coming from operations consistent with the Guidelines. This gives extra importance to the statement above about local community consent even where the miner already has the mineral rights and consent is not required under domestic law. The Guidelines' content includes the following.
I. Background and Challenges
II. Objective
III. Scope of Application
IV. Introduction to Basic Steps of Risk-based Due Diligence
V. Risk Categories for Due Diligence
VI. Warning Signs
VII. Framework and Proces ses for Due Diligence
VIII. Audit, Certification and Oversight
Annex: Model Supply Chain Policy

\section{J. Natural Resource Charter (2014) [23]}

This is the second edition of the Natural Resource Charter and describes 12 precepts on how a country and its government might transform extractive wealth into sustained prosperity, including citizens and the international community ([23], p4). The Charter was developed, through the Natural Resource Governance Institute, by independent practitioners and academics experienced in the challenges faced by resource-rich countries and 'was created in the belief that natural resource wealth can be a powerful tool for social and economic advancement, but only if countries are able to tackle the challenges' ([23], p4). The Charter contains the following 12 precepts, with additional detail and examples presented undereach.

1 Resource management should secure the greatest benefit for citizens through an inclusive and comprehensive national strategy, clear legal framework and competent institutions.

2 Resource governance requires decision makers to be accountable to an informed public.

3 The government should encourage efficient exploration and production operations, and allocate rights transparently.

4 Tax regimes and contractual terms should enable the government to realize the full value of its resources consistent with attracting necessary investment, and should be robust to changing circums tances.

5 The government should pursue opportunities for local benefits, and account for, mitigate and offset the environmental and social costs of resource extraction projects.

6 Nationally owned companies should be accountable, with well-defined mandates and an objective of commercial efficiency.

7 The government should invest revenues to achieve optimal and equitable outcomes, for current and future generations.

8 The government should smooth domestic spending of revenues to account for revenue volatility.
9 The government should use revenues as an opportunity to increase the efficiency of public spending at the national and sub-national levels.

10 The government should facilitate private sector investments to diversify the economy and to engage in the extractive industry.

11 Companies should commit to the highestenvironmental, social and human rights standards, and to sustainable development.

12 Governments and international organizations should promote an upward harmonization of standards to support sustainable development.

\section{K. Local Good Deal: Achieving common prosperity (2014)} [24]

This policy brief proposes recommendations for local government leaders in ASEAN countries to 'exploit new opportunities in ... ASEAN governance structures ... to ensure that the richness of natural resources leads to ... prosperity for ASEAN's citizens' ([24], p1). A short (3 page) document, produced through the Asia Pacific Knowledge Hub for Better Governance on Extractive Industries, this describes the context and rationale for more focus on local government and need for these entities to increase cooperation throughout ASEAN. The document describes three recommendations.

1. Ensure Local Governments and Communities get a Good Deal from Extractive Industry Activities.

2. Equip Local Policy-makers with Capacity to Make Good Deals,

3. Broaden and Up-Scale TransnationalEngagement

\section{Mining and Sustainable Development Framework}

(2013) [25]

The Intergovernmental Forum on Mining Minerals Metals and Sustainable Development (IGF) identifies as 'the leading global intergovernmental policy forum on mining and sustainable development', and this document is the latest version of its agreed framework on 'Mining and Sustainable Development: managing one to advance the other', which the IGF promotes and uses as 'a call to the international community, particularly the UN and donor agencies, to enhance support towards capacity building that promotes the good governance of the mining/metals sector and its contribution to sustainability' ([25], 5). The framework is presented under six areas: Legal and Policy Environment, Financial benefit maximization, Socio-economic benefit maximization, Environmental Management, Post-mining Transition, and Artisanal and Small-scale Mining. In relation to each, the Framework outlines both policy principles and then detailed 'analysis' about the issues arising and matters relevant to implementation. The IGF members adopted the Framework as 'a comprehensive model that, progressively implemented, will allow mining to make its maximu m contribution to the sustainable development of developing countries'[25], 6. While Indonesia is not currently a member, the IGF includes many countries with large mining sectors and relevant experience (including Brazil, Canada, Germany, India, Mongolia, Papua New Guinea, Peru, Russia and South Africa). The Framework is used by various parties to assess a country's 
mining regulation and help identify areas for reform, ${ }^{7}$ and so presents a useful tool. The Framework's detail in relation to Legal and Policy Environment is extracted below.

Legal and Policy Environment: A mature modern legis lative regime is one that provides clear lines of responsibility and accountability. Such a regime provides the foundation of good governance and contributes to sustainable development in all as pects of social and economic life. To this end Governments should consider:

The ongoing generation of and access to geological information

... and making that information available to individuals, communities and other civil society actors with equal acces s to ensure that consultations between different parties can take place on an equal footing.

The revision and periodic updating ofmining codes and standards

Mining codes and standards revised and updated to reflect changing knowledge and best practice. They should deal with all as pects of mining from exploration to closure and post-closure management. The dataand reporting requirements by entities should be made explicit in exploration and operating licences so that authorities can make informed decisions.

A permitting process that requires:

Mining entities, in preparing their applications for a mining permit, to consult with communities and other stakeholders at all stages of the as sessment and planning process and to document the nature and results of their engagement programme in the permit application;

The submis sion of integrated social, economic and environmental as sessments. In addition to a baseline description of current conditions, permit submis sions should describe possible risks and impacts of the mining activities together with proposed mitigation or management measures:

The permit submissions to identify and quantify opportunities and propose programmes that lead to the creation of sustainable benefits over the life of the project;

The permit application to be considered complete only when it includes acceptable plans for the eventual closure of the mine and the provision of adequate financial as surance to cover the costs of closure and any ongoing monitoring;

The permit applications, when applicable, to address indigenous peoples, cultural heritage, resettlement, and community safety and security is sues;

Mining entities to have a process of consultation that provides affected communities with an opportunity to express their views on project risks and impacts, and be consulted on the development of mitigation measures; and

Completion of the process in a timely, transparent, unambiguous and consistent manner' ([25], 6-7).

\section{Mineral \& Energy Resource Exploration (2013) [26]}

Issued by the Australian Government's Productivity Commission, this is a report of an inquiry into the nonfinancial barriers to mineral and energy resource exploration'. The document examines the Australian situation, and therefore is not directly applicable anywhere else. However it does have much of value beyond the Australian context, in the detailed analysis which the
Commis sion gives to the economic and legal dynamics around mining which arise in most countries: concepts of unnecessary regulatory burden, land access, heritage protection, environmental management, pre-competitive geoscience information, and workforce issues. While the specific recommendations identified by the Commission are aimed at Australian governments and stakeholders, the key points reflect is sues and dilemmas which have broader resonance.

Exploration is a very small part of the economy, but the 'sector's significance is in dis covering commercially valuable resources that sustain the operations of mineral and energy extraction industries - which represented' nearly 10 percent of Australia's GDP at that time.

'The number, size and quality of resource discoveries in Australia is declining over the longer term, and the exploration sector is experiencing rising costs and lower productivity.

Governments regulate resource exploration for three broad reasons:

- the mineral and energy resources are owned by the Crown [state]

- exploration may impact on existing and future land uses such as agriculture, or damage sites of environmental and heritage significance

- exploration may have effects beyond the area being explored, such as on the regional environment and nearby communities.

Many stakeholders are dis satisfied with the current regulatory arrangements ... some explorers claim that governments are dis couraging exploration ... some community groups claim that regulations are insufficient to protect [other]... values and ... uses of the land...

Regulatory processes that impose unnecessary burdens on resource explorers or inhibit exploration can be reformed by:

- ensuring stronger and simpler coordination, transparency and accountability of exploration licence approval processes

- making land access decisions that take into account the benefits of exploration to the wider community, and that are appropriate to the level of risk posed by exploration as informed by sound evidence

- improving access to the existing knowledge of Indigenous heritage and accrediting state and territory government proces ses which meet Australian Government standards of Indigenous heritage protection

- addressing ... environmental approvals processes that are duplicative [between national and sub-national governments] and are not commens urate with the risk and significance of the environmental impacts of exploration.

Explorers highly regard the acces sibility and provision of precompetitive data by Australia's geological survey organis ations. However, the effectiveness of state and territory geological survey organis ations is hampered because significant shares of their budgets are from shortterm funding initiatives' ([26], p2).

\section{INDONESIA-SPECIFIC MATERIALS}

There have also been some recent publications summarising Indonesia's mining regulation, or focussing on
The IGF Secretariat has worked with various governments in reviewing and recommending improvements in mining regulation informed by the IGF Framework, including Mongolia, Suriname, Senegal and Uganda. 
aspects of this. A similar literature review helps identify particular is sues of attention.

\section{A. Beneficial Ownership in Indonesia (2018) [27]}

This policy brief outlines the international initiatives on increasing disclosure of beneficial ownership and Indonesian commitments and current structures relevant in this regard. It suggests that challenges to increasing disclosure on beneficial ownership in Indonesia extractives sector include governmental implementation, self-reporting and the lack of certainty around that, and data verification. The document, available in Bahasa Indonesia and English, contains sections detailing the Indonesia Commitment on Beneficial Ownership Disclosure, and Regulatory Framework of Beneficial Ownership Disclosure in Indonesia.

\section{B. Indonesia: Mining (2018) [28]}

The annual publication on Mining, by Getting The Deal Through, comprises summaries of mining law in numerous juris dictions, usually compiled by commercial lawyers from each jurisdiction who advise mining companies and investors. The 2018 section on Indonesia states that 'Given the recent massive changes to the mining regulations, new investors are likely to be cautious entering a business sector in which there is not a settled body of law, and which is likely to remain volatile'. The document contains succinct summaries of Indonesia's principal laws and regulatory bodies that regulate the mining industry, state control \& allocation of mineral rights and third-party rights in that process, information availability, and environmental and social aspects relevant to mining.

\section{Mining in Indonesia (2017) [29]}

This report's foreword opines that 'It is now more than eight years since the 2009 ...Mining Law was promulgated. ...[T] here remain many challenges for investors ... These challenges include but are not limited to: ... protracted $\mathrm{CoW} / \mathrm{CCoW}$ renegotiation process; Difficulties in dealing with the downstream in-country processing requirements under the Mining Law; Foreign shareholder divestment requirements; Lack of coordination between the central, provincial and regional governments; Conflicts between mining operations and forestry regulations; Community relations and labour regulations; and Corruption, collusion and nepotism' ([29], 8). This report is a regular publication by the accountancy firm $\mathrm{PwC}$ and its focus and analysis is clearly informed by its title 'Mining in Indonesia: Investment and Taxation Guide'. It is not offered as an objective or academic analysis of the regulation of mining in Indonesia, but it does give detailed and reasoned insight into how investors and their advisers perceive the current situation. Thus it helps identify areas for attention in considering mining regulation in Indonesia. The report includes the following chapters.

2.0 Regulatory Framework

3.0 Contracts of Work

4.0 Tax Regimes for the Indonesian Mining Sector

5.0 Accounting Considerations
6.0 Additional Regulatory Considerations for Mining Investment

Appendices

AppendixA Minimum in-country processing and refining requirements for metal minerals prior to export

AppendixB Regional Taxes

AppendixC Ministry of Energy and Mineral Resources

AppendixD Indonesian Mining Association \& Indonesian Coal Mining As sociation

AppendixE Summary of CCoW generations

\section{OTHER REGULATORY DYNAMICS}

There are some other materials and perspectives - beyond mining - which provide useful guidance for any analysis or recommendations about mining regulation in any jurisdiction.

\section{A. Regulatory Impact Assessment can help identify and implement improvements}

Regulatory impact assessment (RIA) is a process to systematically assess the benefits and costs of proposed changes to law. This is used in various jurisdictions, when amending or proposing new laws, to help regulators consider all the potential effects (both good and bad) of the proposed regulation, and to structure the regulation in a way most likely to achieve the desired objectives with the least unintended impacts. RIA can also help in analysing current regulation, and broadly involves four processes. ${ }^{8}$

1 Explaining the regulatory context by:(i) identifying the policy objective(s) of the regulatory proposal; and (ii) describing the nature and extent of the 'problem' to be addressed by the regulatory proposal

2 Explaining the proposal, detailing:(i) wording of the new/amended regulations, (ii) legal authority to make that regulation, (iii) groups likely to be affected by the regulation, and (iv) proposals for compliance.

3 Undertaking cost-benefit analysis: (i) outline the benefits and costs expected from the regulatory proposal in relation to each of adminis trative, economic, social, environmental, enforcement and compliance; (ii) compare the proposal's costs and benefits in each of these areas, and also do the same for any practical alternatives to the proposal

4 Describe the consultation and stakeholder involvement, including the above 3 steps

RIA is an intensive process and its application is sporadic in under-res ourced government agencies. ${ }^{9}$ Indonesia has had RIA initiatives for nearly two decades and, in 2009, the Regulatory Impact Analysis Guidelines were launched by the Ministry of National Development Planning/National Development Planning Board. Recent academic as sessment of these Guidelines reports RIA has not been used much, nor well, in Indonesia ([33], 106) but also identifies ways in which RIA and its benefits may better contribute to Indonesian regulation.

'(1) including RIA as a part of the education and training curriculum of leadership;

(2) making RIA an alternative method in the formulation of policies;
Summarised from [30], p21.

A survey of RIA in 'developing and transition countries' indicated that 'it seems that someform of RIA is used in the majority ( 75 percent) of these countries. However, the coverage of RIA, both in terms of types of regulation and number of regulation proposals included, appears to vary widely bet ween countries. Few countries appear to be applying RIA consistently to regulatory proposals affecting economic, social and environmental policies': [31], p295; see also [32], p17. 
(3) implementing socialization and continuous workshops on RIA in various government institutions both at the central and regional levels;

(4) adopting the mindset of RIA, which is als o called concise RIA and/or logic thinking RIA in formulating policies; and

(5) restructuring the budget allocation in the preparation of the regional government policy so that RIA can be implemented in Indonesia' ([33], p108).

\section{B. Dangers in insularity of mining regulation}

The separation of mining law, and mining regulators, from a country's more general regulatory processes can be a double-edged sword. Yes, it enables greater specialis ation and structuring to the particularities of mining operations, but it can also lead to insularity. Law Professsor Neil Gunningham focuses on safety in mining, but the observations in his 2007 book also apply more widely.

'One cons equence of this separation of mining from mainstream ... has been to is olate the industry from legis lative and regulatory developments els ewhere. What became regarded as "next generation regulation" as regards OHS [occupational health \& safety] generally, was largely ignored by the mining sector, its policy-makers and its regulators, who continued to adopt forms of regulation which "mainstream" regulators had long rejected as unlikely to reduce levels of work related injury and disease to anything approaching acceptable levels' ([34], p12).

\section{Consistency with increasing structures around business responsibility}

There are increasing international standards and structures on the responsibility of business to respect human rights, which have relevance for government regulation of mining companies.

In 2011, the UN agreed the UN Guiding Principles on Business and Human Rights [35] (known as the UNGPs) ${ }^{10}$ which emphasise that business has a 'responsibility to respect' human rights, involving three basic aspects. These are that a company should:(1) adopt policies and procedures to res pect human rights standards relevant to their operations, (2) conduct 'due diligence' so they are familiar with their operations and potential human rights impacts, and (3) remedy any impacts which their operations cause/contribute to, and 'use leverage' to reduce impacts with which they are 'directly linked'. ${ }^{11}$ The UNGPs have legal implications for companies in various ways, ${ }^{12}$ with their broadest application under the OECD Guidelines on Multinational Enterprises [38] (OECD Guidelines).

The OECD Guidelines is a government and business agreed code of conduct for responsible business. This has established a complaints mechanism and government's implementation bodies (termed 'National Contact Points') which can address any multinational company from an 'adhering country', which includes many 'home state' countries of mining companies operating in Indonesia (eg. Australia, Brazil, Canada, USA). Any of these companies, if their Indonesian operations are considered contrary to the UNGPs, can be subject to mediation before their home-state 'national contact point'. 13 The OECD Guidelines processes demonstrate companies' operations being meas ured against international human rights standards even where the domestic law can have 'set a lower bar'. ${ }^{14}$ The OECD's guidance documents about extractives due diligence and supply chains - outlined above in $\mathrm{I}(\mathrm{c})$ - are central in informing what is required for compliance with the OECD Guidelines ([20], $\mathrm{p} 10)$. There have been cases where company compliance with domestic mining law has been found insufficient to meet the OECD Guidelines (eg. [40]), where companies have been adjudged inconsistent with the $O E C D$ Guidelines for failing investigate source regarding potential conflict minerals (eg. [41]), and where companies have been called on to use their leverage in government contracts to reduce the human rights impacts linked to their products or services (eg. [42], [43], [44]).

\section{Demanding perfection should not prevent improvement}

Effective law reform involves identifying and implementing what is achievable, and not detailing a 'shopping list' of shortcomings and ideals in the face of limited resources to address these. This has been emphasised and explained in the work of the political scientist Dr Merilee Grindle and her 'good enough governance' concept. This shows that law reform must engage in some very difficult prioritising:

'Working toward good enough governance means accepting a more nuanced understanding of the evolution of institutions and government capabilities; being explicit about trade-offs and priorities in a world in which all good things cannot be pursued at once; learning about what's working rather than focusing solely on governance gaps; taking the role of government in poverty alleviation seriously; and grounding action in the contextual realities of each country, 15

Although Dr Grindle was specifically addressing good governance for development, these observations also have usefuldirection for any analys is or reform proposals in mining regulation

\section{CONCLUDING OBSERVATIONS}

There is no place for an ignorant Australian to advocate 'copying what we do'. Nor - as Dr Grindle well explains - is

10 For a more detailed explanation of the origin and content of the UNGPs, see [36].

11 [35], Guiding Principles 16 (policy commitment), 17 (due diligence) and $22 \& 31$ (remedy); all further explained in [37].

12 These include: (1) companies expressly adopting the UNGPs and reporting against these requirements, (2) industry groups using processes from the UNGPs in their membership requirements, including the International Council on Mining and Metals, (3) governments and companies requiring contractors and suppliers to comply with the UNGPs; and (4) development banks and financiers using UNGP processes in their assessment or expectation of cust omer responsibilities. For greater detail on these developments, see [36], p892-896.

13 As yet there do not appear to be any complaints about mining operations in Indonesia but there have been various complaints and proceedings under the $O E C D$ Guidelines regarding other matters in Indonesia, including: land use in Tuban (East Java) for a cement fact ory (Swiss NCP); workforce of Coca-Cola Company (USNational Cont act Point); and human rights and environment issues of a Japanese multinational in the energy sector in Indonesia (Japanese Contact Point).

14 [38], Ch IV, [38]. A useful summary of the OECD Guidelines operation from 2001-2015 is provided in [39].

15 [45], 525 (see more recent development of the concept in [46] \& [47]). 
there use in some generic 'shopping list' of everything necessary for 'good' mining regulation. Finally, as the Natural Resource Charter candidly acknowledges, resource development and regulation involves complex options and trade-offs. It would be simplistic to suggest there are universals which can be expressed in any detail to be useful to each jurisdiction. But the above analys is does provide some principles and areas which can assist in considering mining regulation in Indonesia. These can be relevant in range of contexts, such as: identifying issues which should be considered where a government decision-maker has a discretion to exercise, or proposals for law-reform.

There seems much support for Indonesia's historic 'contract of work' mining regime, and much criticism of the current law and its implementation. Industry reference to structures and 'ease' of yesteryear is a recurrent theme in many jurisdictions; and comparison often does show that earlier times involved rights being allocated more easily and profits were bigger. But those times featured little controlover environmental and social impacts of mining, and so no sober reflection reasonably expects such a system should be replicated today. Necess arily, therefore, the as sociated profits and 'ease' of rights-allocation which previously existed, are not a valid comparator. Governments and companies see the importance of greater accountability in mining regulation. This is the case in Indonesia, just as it is in other countries, and Indonesia's 1998 changes around regional autonomy ${ }^{16}$ are one of many reasons why earlier contractual forms and practices cannot be replicated today.

\section{A. Local content and development}

There seems much contention around the legal structures seeking to increase local benefit in Indonesia, such as processing, employment, and ownership. When contemplating law reform or problems in implementation, it is often useful not to start with the legal structures. Too often, debates are sought to be fought and won with law alone. For example; companies demanding that a contract from a previous century must be strictly observed, or land owners insisting they have a legal right to veto development. Any structure which is legally established - but which makes little sense according to economics, politics, culture, public health or many other daily realities - usually faces a future of further legal arguments about breach and compliance. A more productive approach can be to seek better understanding between stakeholders in these other areas: economics, politics, culture, transparency, public health and so on. Only once broader processes with stakeholders have produced some consensus or compromise, then is it usefulto turn to how the law might implement that.

The ideas and structures of RIA can be useful, combined with much of the economic and governance ideas outlined in the international documents summarised earlier in this paper. If a stakeholder group is insisting on a certain position, they should be invited to consider the broader benefits and costs of that to all parties involved. These types of approaches can be seen in the detailed guidance of the three lengthy studies released earlier this year about open contracting, local content, and managing mining for sustainable development: [1], [2] \& [4]. As regards local procurement, the 2017 reporting mechanism is relevant: [19]. These all have useful ideas and tools for stakeholders in seeking how to progress local content arrangements with most likelihood of achieving desired results and gaining broad acceptance.

\section{B. Consistency with business \& human rights}

As outlined earlier, there is increasing attention to the human rights impacts of business operations, and increasing structures under which these are being monitored. This can be directly in relation to the company, or through financiers and customers. These various pressures mean that mining companies will have reservations about mining law rights and procedures which involve significant human rights impacts.

Useful guidance here can be drawn from the UN's 2018 sourcebook sections on 'protecting the environment and people', and the Natural Resource Charter and IGF's Mining and Sustainable Development Framework (all summarised in section I, above). RIA processes also suggest reference to relevant international standards, and a structure within which these can inform local regulation and implementation.

\section{Government's governance}

Indonesia faces tremendous challenges, as the world's fourth most-populous country, and governance acros s over 30 provinces and thousands of islands. This is an additional complexity on top of the normal difficulties that most mining jurisdictions face, of seeking governmental efficiency between agencies. The benefits and impacts from mining operations invariably cross the responsibility of multiple government agencies. Most jurisdictions struggle with ensuring a consistency, and avoiding unnecess ary duplication, between government agencies. Government officers, on whom implementation of any regulation will depend, are also a party whose interests should be considered in assessing or proposing changes to Indonesia's mining regulation. Devolution from central government, if done too quickly and without capacity and support, can lead to inconsistent regulation of mining and misuse of funds. This is a problem which Indonesia appears to have encountered (eg. [49], p6; [33], p106) in common with other significant mining juris dictions including Peru and Argentina.

Again, RIA can provide assistance in considering these issues in mining; and the 2018 study on RIA in Indonesia identifies some useful guidance (see IIIA above). Greater accountability and transparency can assist in keeping interested parties informed of regulatory proposals, but also in making them aware (and encouraging their consideration) of broader interests which will also be affected by the particular regulation. The UN's 2018 sourcebook has much of value in seeking to structure any regulation to better contribute to sustainable development (see ICabove). The challenge is how to use this material in a way which gains domestic 'ownership'. This is reinforced by recent reflections on the use (and misuse!) of RIA.

' $[\mathrm{T}]$ he fundamental and inevitable difficulty its [RIA] proponents face is that policy making is an inherently political process, one deeply embedded in liberaldemocratic systems of government. This is a difficulty, perhaps an insurmountable one, as the wishes of the electorate do not always coincide with the requirements of a rational, evidence-based decision-making process such as that at the core of prescribed RIA processes.... It often takes a series of compromises between the competing

\footnotetext{
16 The relationship to mining regulation is described in [48], 5.
} 
parties before agreement can be reached as to the content of a new or modified regulation.' ([50], p120-121).

Indonesia - like every other major mining jurisdiction faces complexities with mining regulation for which there is no 'easy answer'. As with other mining countries, domestic regulatory-making processes can be improved by better understanding and use of RIA and the array of recent, useful international guidance in the area.

\section{REFERENCES}

[1] [Pitman, R., Shafaie, A., Hayman, G., and Kluttz, C.: Open Contracting for Oil, Gas and Mineral Rights: Shining a Light on Good Practice (Open Contracting Partnership, Natural Resource Governance Institute, 2018)

[2] Cosbey, A., and Ramdoo, I.: Local Content Policies (Intergovernmental Forum on Mining Minerals Metals and Sustainable Development, International Institute for Sustainable Development, 2018)

[3] RMF: Responsible Mining Index 2018 (Synergy, Responsible Mining Foundation, 2018)

[4] Gankhuyag, U., and Gregoire, F.: Managing mining for sustainable development: A sourcebook (UN Environment, United Nations Development Programme, 2018)

[5] ASEAN: Sustainable Minerals Development: Best Practices in ASEAN (Community Relations Division, ASEAN Secretariat, 2017)

[6] AU: Addis Ababa Declaration on Building a Sustainable Future for Africa's Extractive Industry - From Vision to Action (Conference of Ministers Responsible for Mineral Resources Development, African Union, 2011)

[7] EC: The raw materials initiative - meeting our critical needs for growth and jobs in Europe (Commission, Commission of the European Communities, 2008)

[8] ASEAN: ASEAN Minerals Cooperation Action Plan 2016-2025 (ASEAN Ministerial Meeting on Minerals, ASEAN Secretariat 2015)

[9] ASEAN: ASEANReporting Mechanism to Monitor the Adoption of Sustainability Assessment Frameworks and Tools for the Minerals Sector (ASEAN Secretariat, Association of SE Asian Nations, 2017)

[10] ASEAN: Joint Media Statement of the 6th ASEAN Ministerial Meeting on Minerals (ASEAN Ministerial Meeting on Minerals, ASEAN Secretariat, 2017)

[11] Azapagic, A.: 'Developing a framework for sustainable development indicators for the mining and minerals industry', Journal of Cleaner Production, 2004, 12, (6), pp. 639-662

[12] GRI: GRI 101: Foundation (GRI Secretariat, Global Reporting Initiative, 2016)

[13] UN: Indicators of Sustainable Development: Guidelines and Methodologies (Department of Economic and Social Affairs, United Nations, 2007)

[14] THA Gov: Review of SustainabilityAssessment Tools for Minerals Sector (Department of Primary Industry and Mines, Royal Thai Government, 2014)

[15] Standards Australia: Life-Cycle Costing - An Application Guide Council of Standards Australia, and Council of Standards New Zealand, Standards Australia, 2013)

[16] Ness, B., Urbel-Piirsalu, E., Anderberg, S., and Olsson, L.: 'Categorising tools for sustainability assessment', Ecological Economics, 2007,60,(3), pp. 498-508

[17] http://www.epa.ie/monitoringassessment/assessment/eia/, 'Environmental Impact Assessment' (Government of Ireland) accessed 6 Aug 2018

[18] Cameron, P., and Stanley, M. (Ed.)^(Eds.): 'Oil, Gas, and Mining' (World Bank, 2017, edn)

[19] Geipel, J., Nickerson, E., Kielty, J., and Regenstrief, T.: Mining Local Procurement Reporting Mechanism (Borders, E.W. Deutsche Gesellschaft fur Internationale Zusammerarbeit $\mathrm{GmbH}$, 2017)

[20] OECD: OECD Due Diligence Guidance for Meaningful Stakeholder Engagement in the Extractive Sector (Secretary-
General of the OECD, Organisation for Economic Co-Operation and Development, 2017)

[21] OECD: Due Diligence Guidance for Responsible Supply Chains of Minerals from Conflict-Affected and High-Risk Areas (Secretariat, Organisation forEconomic Co-operation \& Development, 2016)

[22] CCCMC: Chinese Due Diligence Guidelines for Responsible Mineral Supply Chains China Chamber of Commerce of Metals, Minerals and Chemicals Importers \& Exporters, 2015)

[23] NRGI: Natural Resource Charter (Natural Resource Governance Institute, 2014)

[24] JPP: A Local Good Deal: achieving common prosperity through extractive industries in Southeast Asia (Department of Politics and Government, Universitas Gadjah Mada, 2014)

[25] IGF: Mining and Sustainable Development: managing one to advance the other (Intergovernmental Forum on Mining Minerals Metals and Sustainable Development, Intergovernmental Forum Secretariat (Foreign Affairs, Trade and Development Canada), 2013)

[26] AUS Gov: Mineral and Energy Resource Exploration (Productivity Commission, Australian Government, 2013)

[27] Ananda Wulan SR, R.: Beneficial Ownership Disclosure in Indonesia: Close the Loops for Advancing Governance Open Government Indonesia, Transparency International Indonesia, Open Government Partnership, Kementerian PPN, and PPATK (Indonesian Financial Transaction Reports and Analysis Centre), Publish What You Pay, 2018)

[28] Situmorang, R., Soemadipradja, R., and Reid, R.: 'Indonesia', in Bourassa, M., and Turner, J. (Eds.): 'Mining' (Getting The Deal Through, 2018)

[29] PWC: Mining in Indonesia (PwC Indonesia, PwC, 2017)

[30] Southalan, J., Bennett, M., Kusaasira, D., Thein Oo, U., and Gabriel, L.: Parliaments and Mining Agreements: Reviving the Numbed Arm of Government (University of Western Australia Faculty of Law, International Mining for Development Centre, 2015)

[31] Kirkpatrick, C., Parker, D., and Zhang, Y.-F.: 'Regulatory Impact Assessment in Developing and Transition Economies: A Survey of Current Practice', Public Money \& Management, 2004, 24, (5), pp. 291-296

[32] Welch, D., and Waddington, R.: 'Introducing Regulatory Impact Assessment in Developing Countries: The Case of Uganda'. Proc. International Conference on Reforming the Business Environment, Cairo, 30 Nov 20052005 pp. Pages

[33] Kurniawana, T., Muslima, M.A., and Sakapurnamab, E.: 'Regulatory impact assessment and its challenges: An empirical analysis from Indonesia', Kasetsart J Social Sciences, 2018, 39, (1), pp. 105-108

[34] Gunningham, N.: Mine Safety (Federation Press, 2007)

[35] UN: Guiding Principles on Business and Human Rights: Implementing the United Nations "Protect, Respect and Remedy" Framework (Special Representative of the Secretary-General on the issue of human rights and transnational corporations and other business enterprises, United Nations Human Rights Council, 2011)

[36] Southalan, J.: 'Human rights and business lawyers: The 2011 watershed', Australian Law Journal, 2016,90, (12), pp. 889-907

[37] UN: The Corporate Responsibility to Respect Human Rights: An Interpretive Guide (Office of the UN High Commissioner for Human Rights, United Nations, 2012)

[38] OECD: OECD Guidelines for Multinational Enterprises (Organisation for Economic Co-operation \& Development, OECD Publishing, 2011)

[39] OECD: Implementing the OECD Guidelines for Multinational Enterprises (Secretary-General of the OECD, Organisation for Economic Co-Operation and Development, 2016)

[40] NOR NCP: Complaint from The Future In Our Hands (FIOH) against Intex Resources Asa and the Mindoro Nickel Project (Norges OECD-kontaktpunkt, Norwegian National Contact Point for the OECD Guidelines for Multinational Enterprises, 201 1)

[41] GBR NCP: Statement DAS Air (UK National Contact Point for the OECD Guidelines for Multinational Enterprises, Department for Business, Innovation \& Skills, 2008) 
[42] NLD NCP: Final Statement Bart Stapert, attorney, vs Mylan (Nationaal Contactpunt OESO-richtlijnen, Ministry of Foreign Affairs, 2016)

[43] FRA NCP: "Etienne Lacroix - Alsetex in Bahrain" - Specific Instance (French National Contact Point, Ministère de l'Économie et des Finances, 2016)

[44] GBR NCP: Final Statement after Examination of Complaint: Privacy International \& Gamma UK International Ltd (UK National Contact Point for the OECD Guidelines for Multinational Enterprises, Department for Business, Innov ation and Skill, 2015)

[45] Grindle, M.: 'Good Enough Governance: Poverty Reduction and Reform in Developing Countries', Governance, 2004, 17, (4), pp. 525-548

[46] Grindle, M.: 'Good Enough Governance Revisited', Development Policy Review, 2007, 25, (5), pp. 533-574

[47] Grindle, M.: Good Governance: The Inflation of an Idea (Center for International Development, Harvard University, 2010)

[48] Sullivan, W., and Purwono, C.T.: Mining Law and Regulator Practice in Indonesia: A Primary Reference Source (John Wiley \& Sons, Inc, 2013)

[49] McKay, J., and Bhasin, B.: 'Mining Law and Policy in Indonesia: Issues in Current Practice that Need Reform', J Energy \& Natural Resources L, 2001, 19, (4), pp. 1-16

[50] Carroll, P., Deighton-Smith, R., Silver, H., and Walker, C.: Minding the Gap: Appraising the promise and performance of regulatory reform in Australia (Australian National University E press, 2008) 